\title{
Effect of arsenic on Amaranthus gangeticus
}

\author{
M. Z. Hossain, Sushmita Dey and M. S. Islam
}

Soil Science Discipline, Khulna University, Khulna-9208, Bangladesh

Received: 21 May 2017

Revised: 07 February 2018

Accepted: 23 May 2018

DOI: http://dx.doi.org/10.3329/bjsir.v53i4.39189

\begin{abstract}
Groundwater arsenic contamination has become a threat to the crop production potential in the soils of vast areas of Bangladesh. Situation is grave in some districts of the country, particularly the southern part. A pot experiment was conducted to investigate the effects of arsenic treated irrigation water $\left(0,1,2,5\right.$ and $\left.10 \mathrm{mgL}^{-1}\right)$, where a total of ten (10) irrigations were provided thus the treatments received $0,10,20,50$, and $100 \mathrm{mg}$ arsenic (As) pot $^{-1}$. Effects of applied levels of arsenic on Amaranthus gangeticus (Lal shak) were evaluated in terms of the growth, yield, major nutrients' content, and their translocation in the plant. As treatments significantly reduced $(p \leq 0.05)$ the dry weight of shoot and root by $19.31 \%$ and $44.03 \%$ respectively. Both total and available concentrations of nitrogen $(\mathrm{N})$, potassium $(\mathrm{K})$ and sulfur $(\mathrm{S})$ were significantly $(\mathrm{p} \leq 0.05)$ suppressed by the As treatments, while only higher three doses significantly $(\mathrm{p} \leq 0.05)$ affected both levels of concentrations of phosphorus $(\mathrm{P})$, calcium $(\mathrm{Ca})$ and magnesium $(\mathrm{Mg})$. Translocation coefficients for soil to root for $\mathrm{P}, \mathrm{K}, \mathrm{S}$, and $\mathrm{Mg}$ were significantly reduced $(\mathrm{p} \leq 0.05)$, while translocation coefficients for root to shoot were significantly increased $(\mathrm{p} \leq 0.05)$ for $\mathrm{K}$ and $\mathrm{S}$ by 5 and $10 \mathrm{mgL}^{-1}$ of arsenic treatments.
\end{abstract}

Keywords: Arsenic; Nutrient concentration; Translocation coefficient and Amaranthus gangeticus

\section{Introduction}

Bangladesh, a country of agriculture, grows different types of crops and vegetables all around the year and needs irrigation in different extents. About 30 to 40 percent of the net cultivable area of our country is under irrigation and ground water is the main source (more than 60 percent) of irrigation water. But ground water in 60 out of 64 districts has been reported to be contaminated with various degrees of arsenic (As) concentration (Huq et al., 2003). But its sources have not been clearly identified yet. Some researchers have reported that groundwater contamination with As is attributed to the anthropogenic sources (Anawar et al., 2002). The most As contaminated part of the country lies in the southern regions covering the districts Chandpur, Comilla, Noakhali, Munshiganj, Faridpur, Madaripur, Gopalganj, Shariatpur and Satkhira. Contamination has also been found in South-west, part of North-west, North-east and North Central regions (Ahmed et al., 2011). Smith et al. (2001) reported that in many areas of Bangladesh As concentrations in ground water were more than $50 \mathrm{mg} \mathrm{L}^{-1}$. They also suggested that long-term use of As-contaminated irrigation water could result in As accumulation in the soil and could be absorbed by the vegetables crops. In an experiment with high-arsenic concentration in soil, As changed the concentration, accumulation and translocation of other nutrient elements in plants; vegetable plants in that soils absorbed As in toxic levels, concentrated into plant body, and ultimately affected the growth and yield after metabolism of As species by vegetables (Farid et al., 2003).

The most widely cultivated and the most widely consumed vegetable, Amaranthus gangeticus is a high nutritional value, short duration crop grown round the year in Bangladesh. Several researchers evaluated the adverse effect of As in crop field (Norra et al., 2005) and its accumulation by plants (Sheppard, 1992). 
Most of the vegetable growers in Bagerhat district grow Amaranthus gangeticus and all the people consume this more than any other leafy vegetables (BCAS, 2013). The author, under the scope of no such research conducted in the soils of this area, intends to investigate the extent of harm it can cause to the growth, yield of this vegetable and its subsequent effects on the concentration, accumulation and translocation of other nutrients as well.

\section{Materials and methods}

Soil samples were collected from areas of intensive vegetable cultivation under Bagerhat district (23 $12^{\prime \prime} \mathrm{N}$ and 89 $15^{\prime \prime} \mathrm{E}$ ). Amaranthus gangeticus plants were grown in earthen pots in the field laboratory for 6 weeks ( $4^{\text {th }}$ February to $17^{\text {th }}$ March, 2013) and irrigated with water containing five different levels of arsenic: 0, 1, 2, 5 and $10 \mathrm{mgL}^{-1}$ (T0, T1, T2, T3 and T4, respectively). A total of ten (10) irrigations were provided thus the treatments received $0,10,20,50$, and $100 \mathrm{mg}$ arsenic pot $^{-1}$, respectively. All the treatments were replicated three times. Nitrogen, phosphorus, sulfur and zinc were applied at recommended doses (BARC, 1997). The pots were arranged in completely randomized design. Soil $\mathrm{pH}$ was determined electrochemically at 1:2.5 soil:water ratio by using a glass electrode $\mathrm{pH}$ meter as described by Jackson (1973). Electrical conductivity (EC) of the soil was measured at a soil: water ratio of $1: 5$ by EC meter (USSLS, 1954). Available $\mathrm{Na}^{+}, \mathrm{K}^{+}$, $\mathrm{Ca}^{2+}$, and $\mathrm{Mg}^{2+}$ of soil samples were extracted with $1 \mathrm{~N}$ $\mathrm{NH}_{4} \mathrm{OAc}$ solution $(\mathrm{pH}=7.0)$ as described by Piper (1950) and Jackson (1962). $\mathrm{Na}^{+}$and $\mathrm{K}^{+}$were determined with the help of a flame photometer and $\mathrm{Ca}^{2+}$ and $\mathrm{Mg}^{2+}$ were determined by EDTA titration method. The properties of soil before application of treatments are presented in the Table I.

\section{Table I: Characteristics of soil}

\begin{tabular}{ll}
\hline Properties of soil & Analysis \\
\hline $\mathrm{pH}$ & 7.93 \\
$\mathrm{EC}$ & 1.96 \\
$\mathrm{CEC}\left(\mathrm{cmol}_{\mathrm{c}} \mathrm{kg}^{-1}\right)$ & 20.25 \\
Texture & Silty Clay Loam \\
Organic carbon $(\%)$ & 0.68 \\
Moisture $(\%)$ & 4.70 \\
Available $\mathrm{N}\left(\mathrm{mgkg}^{-1}\right)$ & 104.50 \\
Available $\mathrm{P}\left(\mathrm{mgkg}^{-1}\right)$ & 29.65 \\
Available $\mathrm{K}\left(\mathrm{mgkg}^{-1}\right)$ & 27.48 \\
Available $\mathrm{S}\left(\mathrm{mgkg}^{-1}\right)$ & 10.39 \\
Available Ca $\left(\mathrm{mgkg}^{-1}\right)$ & 290.00 \\
Available $\mathrm{Mg}\left(\mathrm{mgkg}^{-1}\right)$ & 40.00 \\
\hline
\end{tabular}

Agronomic parameters and nutrient content of the plant were determined by recommended methods. Translocation of nutrients from soil to root was measured by which is given below:

$$
T F_{\text {root }}=\frac{C_{\text {root }}}{C_{\text {soil }}}
$$

Translocation of nutrients from root to shoot was measured by which is given below:

$$
T F_{\text {shoot }}=\frac{C_{\text {shoot }}}{C_{\text {root }}}
$$

Where, $C_{\text {soil }}, C_{\text {shoot }}$ and $C_{\text {root }}$ are nutrients concentration in the soil $\left(\mathrm{mg} \mathrm{kg}^{-1}\right)$, shoot $\left(\mathrm{mg} \mathrm{kg}^{-1}\right)$ and root of plant $\left(\mathrm{mg} \mathrm{kg}^{-1}\right)$, respectively. $T F>1$ represent that translocation of nutrients effectively was made to the root from soil and to the shoot from root (Fayiga and Ma, 2006). The level of significance of the different treatment means were calculated by Duncan's new multiple range test (DMRT) and least significant difference (LSD) techniques (Zaman et al., 1982).

\section{Results and discussion}

\section{Effects of arsenic on yield and yield components}

Effects of different levels of As on yield and yield parameters are summarized in Table II. The result showed that with increasing arsenic concentration in irrigation water the number of plants per pot (15), shoot length $(18.14 \mathrm{~cm})$, stem circumference $(1.68 \mathrm{~cm})$ and number of leaves per plant (8.15) decreased significantly $(\mathrm{p} \leq 0.05)$ from the control. Maximum reduction in fresh matter (26.85gm) and dry matter yield $(3.05 \mathrm{gm})$ was found at the highest arsenic treatment (T4) which reduced the fresh and dry mater yield by $19.48 \%$ and $19.31 \%$ respectively and biological yield by $19.42 \%$ over control. At T4 treatment fresh matter productions of root decreased by $47.32 \%$ while the dry matter decreased by $44.03 \%$. The dry matter production of root at T3 did not show any significant change with T4. This confirms that root was affected first than shoot due to arsenic contamination. Reduction in growth and yield parameters was due to the uptake and accumulation of arsenic in plant.

Choudhury et al. (2008) found similar results in which they observed a decrease in the growth and yield parameters of red amaranth due to arsenic toxicity. 
Table II. Yield components of Amaranthus gangeticus and changes of yield due to treatment

\begin{tabular}{llllllllll}
\hline Treatment & $\begin{array}{l}\text { No of } \\
\text { Plants } \\
\text { per pot }\end{array}$ & $\begin{array}{l}\text { Shoot } \\
\text { length } \\
(\mathrm{cm})\end{array}$ & $\begin{array}{l}\text { Stem } \\
\text { circumf } \\
\text { erence } \\
(\mathrm{cm})\end{array}$ & $\begin{array}{l}\text { No of } \\
\text { leaves } \\
\text { per } \\
\text { plant }\end{array}$ & $\begin{array}{l}\text { Shoot } \\
\text { fresh } \\
\text { matter } \\
(\mathrm{gm})\end{array}$ & $\begin{array}{l}\text { Shoot } \\
\text { dry } \\
\text { matter } \\
(\mathrm{gm})\end{array}$ & $\begin{array}{l}\text { Root } \\
\text { fresh } \\
\text { matter } \\
(\mathrm{gm})\end{array}$ & $\begin{array}{l}\text { Root dry } \\
\text { matter } \\
(\mathrm{gm})\end{array}$ & $\begin{array}{l}\text { Yield } \\
\text { decrease } \\
\text { over } \\
\text { control }(\%)\end{array}$ \\
\hline $\mathrm{T} 0$ & $20 \mathrm{a}$ & $19.53 \mathrm{a}$ & $1.79 \mathrm{a}$ & $8.83 \mathrm{a}$ & $33.32 \mathrm{a}$ & $3.78 \mathrm{a}$ & $8.98 \mathrm{a}$ & $1.34 \mathrm{a}$ & 0.00 \\
$\mathrm{~T} 1$ & $20 \mathrm{a}$ & $19.17 \mathrm{ab}$ & $1.78 \mathrm{~b}$ & $8.75 \mathrm{a}$ & $32.37 \mathrm{~b}$ & $3.68 \mathrm{~b}$ & $9.38 \mathrm{~b}$ & $1.12 \mathrm{~b}$ & 2.85 \\
$\mathrm{~T} 2$ & $19.3 \mathrm{a}$ & $18.93 \mathrm{~b}$ & $1.78 \mathrm{~b}$ & $8.57 \mathrm{~b}$ & $31.33 \mathrm{c}$ & $3.56 \mathrm{c}$ & $6.35 \mathrm{c}$ & $1.08 \mathrm{~b}$ & 5.97 \\
$\mathrm{~T} 3$ & $17.7 \mathrm{~b}$ & $18.83 \mathrm{~b}$ & $1.75 \mathrm{c}$ & $8.53 \mathrm{~b}$ & $30.07 \mathrm{~d}$ & $3.41 \mathrm{~d}$ & $4.30 \mathrm{~d}$ & $0.75 \mathrm{c}$ & 9.75 \\
$\mathrm{~T} 4$ & $15 \mathrm{c}$ & $18.14 \mathrm{c}$ & $1.68 \mathrm{~d}$ & $8.15 \mathrm{c}$ & $26.85 \mathrm{e}$ & $3.05 \mathrm{e}$ & $4.73 \mathrm{e}$ & $0.75 \mathrm{c}$ & 19.42 \\
$\mathrm{SE}( \pm)$ & 0.47 & 0.23 & 0.002 & 0.048 & 0.37 & 0.04 & 0.18 & 0.09 & - \\
$\mathrm{CV}(\%)$ & 3.14 & 1.49 & 0.16 & 0.67 & 1.46 & 1.48 & 3.20 & 11.24 & - \\
\hline
\end{tabular}

Means followed by different letter/s in each column are significantly different $(\mathrm{p} \leq 0.05)$ according to DMRT (SE $=$ Standard error and $\mathrm{CV}=$ Coefficient of variance)

Effects of arsenic on nutrient concentrations in shoot and root

Effects of different levels of arsenic on nutrient concentrations in shoot and root summarized in Table III. The concentration of nitrogen showed a significant $(p \leq 0.05)$ decrease with the increase in arsenic concentration for both root and shoot where the lowest nitrogen concentration was found at the highest arsenic treatment. The activities of nitrate reductase and nitrite reductase enzymes may be affected by arsenic toxicity which results in the lowering of nitrogen concentrations in both root and shoot. Ghosh et al.(2013) found severely reduced nitrate and nitrite contents in both shoot and root of wheat seedlings due to arsenic toxicity. Phosphorus concentration ranged from 5.92 to 12.18 $\mathrm{mgg}^{-1}$ in shoot and 4.17 to $10.37 \mathrm{mgg}^{-1}$ in root (Table III) The concentration in shoot showed a decreasing trend with increasing As treatment but a significant $(\mathrm{p} \leq 0.05)$ decrease was found at T3 and T4 while, in root the concentration was significantly reduced from the control. In both cases highest level of arsenic treatment (T4) gives the lowest concentration

\section{Table III. Nutrient contents in shoot and root}

\begin{tabular}{lccccccccccccc}
\hline \multirow{2}{*}{$\begin{array}{c}\text { Arsenic } \\
\text { Treatment }\end{array}$} & \multicolumn{2}{c}{$\mathrm{N}\left(\mathrm{mgg}^{-1}\right)$} & \multicolumn{2}{c}{$\mathrm{P}\left(\mathrm{mgg}^{-1}\right)$} & \multicolumn{2}{c}{$\mathrm{K}\left(\mathrm{mgg}^{-1}\right)$} & \multicolumn{2}{c}{$\mathrm{S}\left(\mathrm{mgg}^{-1}\right)$} & \multicolumn{2}{c}{$\mathrm{Ca}\left(\mathrm{mgg}^{-1}\right)$} & \multicolumn{2}{c}{$\mathrm{Mg}^{2}\left(\mathrm{mgg}^{-1}\right)$} \\
\cline { 2 - 13 } & Root & Shoot & Root & Shoot & Root & Shoot & Root & Shoot & Root & Shoot & Root & Shoot \\
\hline T0 & $8.28 \mathrm{a}$ & $8.45 \mathrm{a}$ & $10.37 \mathrm{a}$ & $12.18 \mathrm{a}$ & $39.84 \mathrm{a}$ & $51.27 \mathrm{a}$ & $16.54 \mathrm{a}$ & $16.41 \mathrm{a}$ & $14.17 \mathrm{a}$ & $22.92 \mathrm{a}$ & $9.50 \mathrm{a}$ & $12.25 \mathrm{a}$ \\
T1 & $8.08 \mathrm{~b}$ & $8.06 \mathrm{~b}$ & $9.53 \mathrm{~b}$ & $12.01 \mathrm{a}$ & $37.72 \mathrm{~b}$ & $47.81 \mathrm{~b}$ & $15.04 \mathrm{~b}$ & $15.27 \mathrm{~b}$ & $12.50 \mathrm{~b}$ & $22.08 \mathrm{a}$ & $9.00 \mathrm{a}$ & $8.50 \mathrm{~b}$ \\
T2 & $7.89 \mathrm{c}$ & $8.00 \mathrm{~b}$ & $8.01 \mathrm{c}$ & $11.33 \mathrm{ab}$ & $34.53 \mathrm{c}$ & $46.22 \mathrm{~b}$ & $11.34 \mathrm{c}$ & $13.65 \mathrm{c}$ & $11.25 \mathrm{c}$ & $20.42 \mathrm{~b}$ & $8.25 \mathrm{a}$ & $7.25 \mathrm{~b}$ \\
T3 & $7.75 \mathrm{~d}$ & $7.54 \mathrm{c}$ & $6.37 \mathrm{~d}$ & $9.19 \mathrm{~b}$ & $28.16 \mathrm{~d}$ & $39.84 \mathrm{c}$ & $7.57 \mathrm{~d}$ & $9.68 \mathrm{~d}$ & $9.17 \mathrm{~d}$ & $17.92 \mathrm{c}$ & $5.00 \mathrm{~b}$ & $4.75 \mathrm{c}$ \\
T4 & $7.09 \mathrm{e}$ & $7.18 \mathrm{~d}$ & $4.17 \mathrm{e}$ & $5.92 \mathrm{c}$ & $19.92 \mathrm{e}$ & $34.00 \mathrm{~d}$ & $4.00 \mathrm{e}$ & $7.22 \mathrm{e}$ & $8.75 \mathrm{~d}$ & $14.58 \mathrm{~d}$ & $1.50 \mathrm{c}$ & $1.75 \mathrm{~d}$ \\
$\mathrm{SE}( \pm)$ & 0.039 & 0.036 & 0.336 & 1.01 & 0.87 & 1.15 & 0.54 & 0.36 & 0.37 & 0.745 & 0.59 & 0.85 \\
C V $(\%)$ & 0.61 & 0.57 & 5.36 & 12.28 & 3.34 & 3.22 & 6.03 & 3.50 & 4.09 & 4.66 & 10.89 & 15.11 \\
\hline
\end{tabular}

Means followed by different letter/s in each column are significantly different $(\mathrm{p} \leq 0.05)$ according to DMRT $(\mathrm{SE}=\mathrm{Standard}$ error and $\mathrm{CV}=$ Coefficient of variance $)$ 
of phosphorus. Competitive effect between arsenate $\left(\mathrm{AsO}^{3-}\right)$ and phosphate $\left(\mathrm{PO}_{4}^{3-}\right)$ ion may suppress the phosphate uptake by the plant resulting in the reduced accumulation of phosphate in shoot and root. Chen et al. (2002) reported that arsenic compete with phosphate for uptake by plants and suppress the phosphate-arsenate uptake system resulting in a lower accumulation of phosphate. The effect of arsenic on potassium content is shown in Table III. The values of potassium significantly $(\mathrm{p} \leq 0.05)$ decreased both in shoot and root with increasing arsenic concentration except in $\mathrm{T} 1$ and $\mathrm{T} 2$. In both cases the highest content of potassium was found in T0 (51.27 mgg- ${ }^{-1}$ in shoot and $39.84 \mathrm{mgg}^{-1}$ in root) and lowest content was found in T4 treatment $\left(34.00 \mathrm{mgg}^{-1}\right.$ in shoot and $19.92 \mathrm{mgg}^{-1}$ in root) The decrease in $\mathrm{K}^{-}$content may be due to the potassium ion may form complexes with the anionic form of arsenic and thus decrease the availability of potassium into plants. Quanji et al. (2008) observed a significant decrease in potassium content due to arsenic treatment in both shoots and roots of wheat under hydroponic system. On the other hand, Roy et al. (2012) found greater concentration of potassium in shoot of green Amaranthus and red Amaranthus than root due to arsenic treatment. Sulfur concentration in both shoot and root showed significant $(\mathrm{p} \leq$ 0.05 ) differences among the treatments and it varied from 7.2 to $16.41 \mathrm{mgg}^{-1}$ in shoot and 4 to $16.5 \mathrm{mgg}^{-1}$ for root (Table III). In both cases $\mathrm{T} 4$ gives the lowest concentration than control. The decrease in sulfur concentration in plants may be due to the antagonistic relationship between the anionic forms of sulfate and arsenate. Quanji et al. (2008) found a significant reduction in sulfur in both shoots and roots of wheat under hydroponic system. The concentration of calcium in shoot and root varied from 14.58 to $22.92 \mathrm{mgg}^{-1}$ and 8.75 to 14.17 $\mathrm{mgg}^{-1}$ respectively (Table III). The data of calcium in shoot showed significant $(p \leq 0.05)$ differences among the treatments except T0 and T1. While, in root, a significant difference in $\mathrm{Ca}$ concentration was observed in lower concentration of arsenic but at higher doses it did not show significant difference. This means that root did not suffer at higher level of arsenic than shoot. The lower concentration of calcium in shoot and root may be due to the precipitation of $\mathrm{Ca}$ with arsenate to form insoluble compounds in soil. Bothe et al. (1999) found reduction of the mobility of dissolved calcium with the formation of low solubility calcium arsenate. Magnesium concentration in shoot and root showed a significant $(p \leq 0.05)$ decrease due to increasing arsenic content which ranges from 1.75 to 12.25 $\mathrm{mgg}^{-1}$ in shoot and from 1.50 to $9.50 \mathrm{mgg}^{-1}$ in root. In both shoot and root, arsenic at lower concentration (T1 and T2) did not affect the uptake of $\mathrm{Mg}$ (Table 3) which confirms a reverse trend with the uptake of $\mathrm{Ca}$ ion by the plant. At lower concentration arsenic might play an additive role for what Mg uptake did not hinder. Klei et al. (1997) reported that in hydroponic system, addition of arsenic significantly increased the concentration of $\mathrm{Mg}$ in shoots of bean plants. But at higher concentration of arsenic, $\mathrm{Mg}$ get precipitated with arsenate ion which lowered its solubility as well as uptake by the plant. Voigt et al. (1996) observed similar result.

\section{Effects of arsenic on translocation factor (TF) of nutrients from soil to root and root to shoot}

The effect of arsenic on translocation factor (TF) of different nutrients is for both root and shoot of Amaranthus gangeticus is shown in table IV. The translocation of nutrients significantly reduced with increasing arsenic treatments from soil to root and that from root to shoot (Table IV). Increasing As concentration significantly $(p \leq 0.05)$ varied in their efficacy in reducing translocation. The translocation of nitrogen showed similar decreasing trend both in root and in shoot. Jha and Dubey (2004) observed similar findings working with rice plant. In their experiment, they reported that nitrogen is generally taken up through an active transport system which is an ATP dependent process. As toxicity might have caused a reduction in ATP pool which resulted into a reduction in the ability of the Amaranthus gangeticus to translocate nitrogen from soil to root as well as from root to shoot. For phosphorus, translocation factor indicates that translocation from soil to root was comparatively higher than that from root to shoot. Increasing As concentrations significantly varied in reducing the translocation to root while translocations of $\mathrm{P}$ to shoot were unaffected. Reduction of $\mathrm{P}$ translocation in Amaranthus gangeticus may be due to the antagonistic effect between $\mathrm{As}$ and $\mathrm{P}$ translocation. Reduction of $\mathrm{P}$ uptake in rice because of antagonistic effect between As and $\mathrm{P}$ was reported by Mehrag and Macnair (1990). Translocation of K from soil to root declined with increasing As concentration orderly. Highest translocations of $\mathrm{K}$ from root to shoot was obtained with no-As while that declined significantly with As treated plants. Provided that increasing As concentrations produced insignificant differences in translocation of K. Wallace et al. (1980) reported to find a depression of $\mathrm{K}$ concentration in roots of bush bean plants due to arsenic in the nutrient solution.

Lower concentration of As did not affect translocation of S but higher doses significantly affected $(p \leq 0.05)$ from soil to root while translocation from root to shoot was unaffected even with higher concentration of As (Table IV). The translocation phenomenon for the first case may be due to competition of sulphate and arsenate ion in the soil solution. Merry et al. (1986) in their experiment obtained similar results and reasoned that $\mathrm{S}$ and As exists in soil solution in similar ionic forms (e.g. sulfate and arsenate) and there should be a competition between these two ions. 
Increasing As concentration did not affect translocation of $\mathrm{Ca}$ from soil to root and similar trend was obtained also for the case of root to shoot translocation. The similarity in response of translocation against lower doses of As may be due to the fact that the concentrations applied were close to one another and below threshold concentration for soil. However, the highest As concentration significantly differed from zero-As (control). Results of $\mathrm{Ca}$ translocation in this experiment partially complies with that of Wallace et al. (1980) findings, where they obtained a depression of $\mathrm{Ca}$ concentration in leaves and roots of bush bean plants against increasing As concentration.

Results obtained for translocation of $\mathrm{Mg}$ revealed that lower two doses of As did not affect but higher two concentrations (50 and $100 \mathrm{mg} \mathrm{L}^{-1}$ ) significantly differed in affecting

\section{References}

Ahmed, MAA, Alam MDJ and Mabrur AA (2011), Evaluation of socio-economic impact of arsenic contamination in Bangladesh, Journal of Toxicology and Environmental Health Sciences 3(10): 298-307.

Anawar HM, Akai J, Mostofa KMG, Safiullah S and Tareq SM (2002), Arsenic poisoning in groundwater: Health risk and geochemical sources in Bangladesh, Journal of Environmental International 27: 597-604.

BARC (Bangladesh Agricultural Research Council) (1997), Fertilizer Recommendation Guide, Bangladesh Agricultural Research Council, Farmgate, Dhaka.

Table IV. Translocation factor of nutrients from soil to root and from root to shoot

\begin{tabular}{|c|c|c|c|c|c|c|c|c|c|c|c|c|}
\hline \multirow{2}{*}{$\begin{array}{c}\text { Arsenic } \\
\text { Treatment }\end{array}$} & \multicolumn{2}{|c|}{$\mathrm{N}$} & \multicolumn{2}{|c|}{$\mathrm{P}$} & \multicolumn{2}{|c|}{ K } & \multicolumn{2}{|c|}{ S } & \multicolumn{2}{|c|}{$\mathrm{Ca}$} & \multicolumn{2}{|c|}{$\mathrm{Mg}$} \\
\hline & Root & Shoot & Root & Shoot & Root & Shoot & Root & Shoot & Root & Shoot & Root & Shoot \\
\hline T0 & $3.86 \mathrm{a}$ & $1.02 \mathrm{a}$ & $5.56 \mathrm{a}$ & $1.46 \mathrm{a}$ & $2.18 \mathrm{a}$ & $1.71 \mathrm{a}$ & $8.94 a$ & $1.83 \mathrm{a}$ & $0.27 \mathrm{a}$ & $1.96 \mathrm{a}$ & $0.41 \mathrm{a}$ & $1.33 \mathrm{a}$ \\
\hline $\mathrm{T} 1$ & $3.56 \mathrm{~b}$ & $1.01 \mathrm{a}$ & $5.22 \mathrm{ab}$ & $1.42 \mathrm{a}$ & $2.10 \mathrm{a}$ & $1.42 b$ & $8.91 \mathrm{a}$ & $1.28 \mathrm{~b}$ & $0.25 \mathrm{ab}$ & $1.93 \mathrm{a}$ & $0.38 \mathrm{a}$ & $1.29 \mathrm{a}$ \\
\hline $\mathrm{T} 2$ & $3.10 \mathrm{c}$ & $0.97 \mathrm{~b}$ & $4.69 b$ & $1.41 \mathrm{a}$ & $1.95 \mathrm{~b}$ & $1.34 \mathrm{~b}$ & $7.37 \mathrm{~b}$ & $1.20 \mathrm{bc}$ & $0.25 \mathrm{ab}$ & $1.82 \mathrm{ab}$ & $0.38 \mathrm{a}$ & $0.96 a$ \\
\hline $\mathrm{T} 3$ & $2.92 \mathrm{~d}$ & $0.95 b$ & $4.14 \mathrm{c}$ & $1.26 \mathrm{a}$ & $1.68 \mathrm{c}$ & $1.28 \mathrm{~b}$ & $6.26 \mathrm{c}$ & $1.02 \mathrm{bc}$ & $0.24 \mathrm{ab}$ & $1.76 \mathrm{ab}$ & $0.20 \mathrm{~b}$ & $0.95 \mathrm{a}$ \\
\hline T4 & $2.78 \mathrm{e}$ & $0.10 \mathrm{c}$ & $3.55 \mathrm{~d}$ & $1.17 \mathrm{a}$ & $1.25 \mathrm{~d}$ & $1.26 \mathrm{~b}$ & $4.20 \mathrm{~d}$ & $0.99 \mathrm{c}$ & $0.23 b$ & $1.62 b$ & $0.13 \mathrm{c}$ & $0.88 \mathrm{a}$ \\
\hline $\operatorname{SE}( \pm)$ & 0.065 & 0.01 & 0.25 & 0.17 & 0.05 & 0.07 & 0.40 & 0.12 & 0.01 & 0.29 & 0.03 & 0.24 \\
\hline C V $(\%)$ & 2.46 & 1.02 & 6.48 & 15.16 & 6.48 & 6.08 & 6.91 & 11.53 & 5.88 & 6.36 & 10.79 & 27.64 \\
\hline
\end{tabular}

Means followed by different letter/s in each column are significantly different $(\mathrm{p} \leq 0.05)$ according to DMRT ( $\mathrm{SE}=\mathrm{Standard}$ error and $\mathrm{CV}=$ Coefficient of variance)

translocation of $\mathrm{Mg}$ from soil to root. $\mathrm{Mg}$ Translocation from root to shoot was unaffected by the applied levels of As (Table IV), which may be due to selective translocation. Shaibur (2009) found a significant negative effect on the concentration of $\mathrm{Mg}$ both in shoots and roots of barley plants due to increasing As concentrations.

\section{Conclusion}

As a consequence of arsenic contamination, fresh and dry matter production of the Amaranthus gangeticus decreased at higher concentration of arsenic while root dry matter was affected by lower arsenic concentration. The contents and accumulation of $\mathrm{N}, \mathrm{P}, \mathrm{K}, \mathrm{S}, \mathrm{Ca}$ and $\mathrm{Mg}$ in the shoots and roots of plant show the variations in elemental concentrations due to increasing arsenic concentration.
BCAS (2013), Summary of baseline household survey results: Bagerhat, Bangladesh, CGIAR Research Program on Climate Change, Agriculture and Food Security (CCAFS), Copenhagen, Denmark. Available online at: www.ccafs.cgiar.org.

Bothe J, James V and Brown PW (1999), Arsenic immobilization by calcium arsenate formation, Environmental Science and technology 33: 3806-15. DOI: $10.1021 / \mathrm{es} 980998 \mathrm{~m}$

Chen TB, Fan ZL and Lei MEI (2002), Effect of phosphorus on arsenic accumulation in As-hyperaccumulator: Pteris vittata L. and its implication, China Science Bulletin 47: 1876-1879.

Choudhury MRQ, Islam ST, Alam R, Ahmad I, Zaman W, Sen R and Alam MN (2008), Effects of arsenic on 
Red Amaranth (Amaranthus retroflexus L.), American-Eurasian Journal of Scientific Research 3(1): 48-53.

Farid ATM, Roy KC, Hossain KM and Sen R (2003), A study of arsenic contaminated irrigation water and it's carried over effect on vegetable In: Fate of arsenic in the environment, Eds. Feroze AM, Ashraf AM and Adeel Z, University of Engineering and Technology, Dhaka, Bangladesh, pp 113-121.

Fayiga AQ and Ma LQ (2006), Using phosphate rock to immobilize metals in soils and increase arsenic uptake in Pteris vittata, Science Total Environment 359: 17-25. DOI: org/10.1016/j.scitotenv.2005.06.001

Ghosh S, Saha J and Biswas AK (2013), Interactive influence of arsenate and selenate on growth and nitrogen metabolism in wheat (Triticum aestivum L.) seedlings, Acta Physiologiae Plantarum 35(6): 1873-1885.

Huq SMI, Rahman A, Sultana N and Naidu R (2003), Extent and Severity of Arsenic Contamination in Soils of Bangladesh In: Fate of arsenic in the environment, Ed. Ahmed F. Bangladesh University of Engineering and Technology and the United Nations University.

Jackson ML (1962), Soil chemical analysis, Asia Publishing House, Bombay.

Jackson ML (1973), Soil chemical analysis, Prentice Hall of India Pvt. Ltd., New Delhi.

Jha AB and Dubey RS (2004), Arsenic exposure alters activity behaviour of key nitrogen assimilatory enzymes in growing rice plants, Plant Growth Regulators 43: 259-268.

Klei TR, Carbonell-Barrachina AA, Burlo F, Burgos-Hernandez A, Lopez E and Mataix J (1997), The influence of arsenite concentration on arsenic accumulation in tomato and bean plants, Scientia Horticulturae 71: 167-176.

Mehrag AA and Macnair MR (1990), An altered Phosphate uptake system in arsenate tolerant $H$. lanatus, New Phytologist 16: 29-35.

Merry RH, Tiller KG and Alston AM (1986), The effect of soil contamination with copper, lead and arsenic on the growth and composition of plants, Plant and Soil 95: 225-268. DOI: $10.2136 /$ sssaj1983.03615995004700010009x

Norra S, Berner ZA, Agarwala P, Wagner F, Chandrasekharam D and Stuben D (2005), Impact of irrigation with As rich ground water on soil and crops: a geochemical case study in West Bengal Delta Plain, India, Applied Geochemistry 20: 1890-1906.

Piper CS (1950), Soil and plant analysis, $12^{\text {th }}$ Ed, The university of Adelaide Press, Adelaide, Australia.

Quanji L, Chengxiao HU, Qiling TAN, Xuecheng SUN, Jingjun SU and Yuexiang LIANG (2008), Effects of As on As uptake, speciation, and nutrient uptake by winter wheat (Triticum aestivum L.) under hydroponic conditions, Journal of Environmental Sciences 20: 326-331.

Roy S, Parveen Z and Huq SMI (2012), Effect of Arsenic on the nutrient uptake pattern of Amaranthus, Dhaka University Journal of Biological Science 21(1): 87-96.

Shaibur MR, Kitajima N, Sugawara R, Kondo T, Huq SMI and Kawai S (2009), Effect of arsenic on phytosiderophore and mineral nutrition of barley seedlings grown in iron depleted medium, Soil Science and Plant Nutrition 55(2): 283-293.

Sheppard SC (1992), Summary of phyto-toxic levels of soil arsenic, Water Air and Soil Pollution 64: 539-550.

Smith LH, Smith J and Naidu R (2001), Assessment of Soil-Plant Transfer of Arsenic from Agricultural Soils, Arsenic in the Asia Pacific Region, Journal of Managing Arsenic for the Future 23(3): 156-157.

USSLS (1954), Diagnosis and Improved of Saline, Alkaline Soils, U.S Salinity Laboratory Staff, USDA Hand Book 60.

Voigt DE, Brantley SL and Hennet RJC (1996), Chemical fixation of arsenic in contaminated soils, Applied Geochemistry 11: 633-643.

Wallace A, Mucller RT and Wood RA (1980), Arsennic phytotoxicity and interaction in bush bean plants grown in solution culture, Journal of Plant Nutrition 2: 111-116.

Zaman SMH, Rahman K and Howlader M (1982), Simple lessons from biometry, Bangladesh Rice Research Institute (BRRI), Publication No. 54, Gazipur, Bangladeah. 